\title{
Some thoughts on feed resource management in different ecosystems and socio-economic circumstances
}

\author{
E.R. Orskov \\ International Feed Resources Unit. \\ Macaulay Institule \\ Craigiebuckle; Aberdeen AB15 8QH, United Kingdom
}

(Received 16 April 2002; revised version 13 September 2002; accepted 11 October 2002)

\begin{abstract}
ABSTR $\wedge$ CT
In this article aspects of feed resource management is discussed. It is emphasised that feed resource management is generally poor in developed countries due to high labour costs and relatively low costs of fossil fuel. Similarly, subsidized agriculture in EU and other countries has led to many problems of environmental degradation and sinee subsidies have become part of the cost of land etc., it has not contributed greatly to farm incomes. Drastic changes in the Common $\Lambda$ gricultural Policy will be necessary in the next decade, made necessary also by EU expansion.

Total resource management can be seen practised in many developing countries in whicl crop livestock are not separated and where crop by-product and animal excreta are both valuable resources. When crops and animals are separated as in many so called developed countries, both crop by-products and animal excreta contribute to waste.

Examples are given of systems in which plant, animals and soif are seen in holistic relationslips. Examples are also given on how human food production can be increased by unlocking bonds between lignin, cellulose and hemicellulose.
\end{abstract}

KEY WORDS: resource management, environmental degradation, plant-soil-animal interactions

\section{INTRODUCTION}

Management of feed resources vary greatly in different parts of the world. There are many reasons for these differences, some of which I will attempt to discuss. It is, however, very complex and influenced by numerous factors including cost of fossil fuel, cost of labour, socio-economic circumstances, climate, soil and many others. 


\section{Resource management in developed countries}

In this respect the so-called developed countries are not very efficient. The total use of renewable resources is mainly due to the high cost of labour and low cost of fossil fuel. Much fossil fucl is being used to replace labour in agriculture, but not only this, the use of by-products in agriculture is often not economic.

Until recently, the largest proportion of straw was simply burned, as it was cheaper than using it. This practice has now been forbidden in many countries. Sometimes, however, the straw is chopped, only to be ploughed in. While this, on the face of it, seems more desirable, as it returns organic matter to the soil, the process of decomposition of the straw is essentially like slow burning as only the lignin is eventually left in the soil.

The impact of fossil fuel used in food production, as a replaccment for labour, is quite enormous. Blaxter (1989) calculated that, for instance, each calorie we digested as food in the west is supported by 10 calories of support energy through the input of fossil fucl in cultivation, fertilizer, harvesting, drying, fecd processing, cooking and waste disposal.

In the so-called developed countries, plant and animal production has in many places been separated. Crop by-products are often a waste and sometimes need an economic input for disposal. Intensive animal production, on the other hand, has similar problems of disposal of excreta. In many instances the use of artificial fertilizer is cheaper than manure. The disposal of excreta thus incurs a cost. On the other hand, in traditional crop livestock systems, both crop by-products and animal excreta are valuable resources, as the crop by-products can be fed to animals and their excreta in tum fertilize the land. This is still the case in most cropping arcas in developing countries.

It is also the case in some Eastern European countries such as Poland and the countries previously belonging to Yugoslavia. The large majority of farms are small crop and livestock farms but here the emphasis is to make farms larger to be more cconomic. Alternatives should be carefully considered, such as part-time farming, with emphasis on less specialized animals and more diversified production, perhaps with organic status.

\section{Special EU problems}

The Common Agricultural Policy (CAP) set up originally to support maximum production has led to many undesirable consequences. Production targets for commodities were achieved many years ago with consequent mountains of meat and milk products. This high production was mainly achicved by heavy use of fertilizers and cropping on marginal lands. Farmers had to be supported to achieve a reasonable living standard in these latter areas, but due to the diversity of clima- 
te and socio-economic conditions in different parts of the $\mathrm{EU}$, what was correct in one place had undesirable consequences in another area. For example, what was as a method to support small farmers in South of France and Germany had undesirable environmental consequences for large farms in the North of France and the South of the UK as they focussed on the highly mechanized production of monocultures. Appropriate subsidies on animals in one area led to undesirable consequences of over-grazing in other areas. Crop subsidies on crops such as linseed were such that sometimes harvesting was not important. One effect is to distort the price of land as potential subsidies inflate the price. The price of purchasing beef cattle and sheep is geared to the potential subsidies. Each castrated male beef animal in the UK currently receives about $£ 230$ in subsidies. In spite of these subsidies, farm income is low. Subsidies have become part of the problem and not the solution to farm incomes. There is no doubt that the agricultural support policies in EU have to be changed drastically to promote environmentally sustainable production. In recent years, it has been increasingly recognized that the present system needs to be drastically changed both for economic and environmental reasons.

In the UK a recent report, Farming and Food, produced by John Curry in 2001 for the British Government made some suggestions as to the way forward. The report argues that the "CAP must be phased out as, in the end, consumers are paying more for their food than at world market prices. Some aspects of the environment are being damaged and farm incomes are unacceptably low. Production subsidies have distorted many aspects of farming in the EU'. There will also be a big problem in changing the CAP at the same time as the EU is being extended. Changing any farm support system to be aimed at desirable environmental issues and sustainable market-oriented production will no doubt be an issue. This will have serious implications for research in the EU. It will need to be more holistic in which animal production and animal science will be seen in their proper interaction with plants and soil. So much of animal research has been aimed at achieving the highest possible yields by controlling the cnvironmental rather than aiming at an animal production system to match the available resources including climate and feeds. The same has been the case for crops with maximum and unsustainable fertilizer use leading to soil crosion, sometimes accumulation of $\mathrm{N}, \mathrm{P}$ and $\mathrm{K}$ to undesirable levels given problems of water catchment pollution and cropping on land that should not be cultivated. The challenge to animal research will be to develop animal production systems and animal breeds suitable to exploit the available resources and the socio-economic conditions including part-time farming as discussed in a previous paper (Orskov, 1992).

This change will no doubt lead to the encouragement of the better use of renewable resources and the development of methods as to how this can best be achieved, including the use of present-day vegetable and other food waste from supermarkets which are currently deposited in land fill, as feeds for which animals can extract 67 to $80 \%$ of their metabolizable energy. This is surely an area which urgen- 
tly needs attention. There now exists a political climate in which the preservation or improvement of the environment has been placed higher on the agenda. Quick fixes, such as genetic modification of crops, are and should be viewed critically by the consuming public; perception of wholesomeness of food is important particularly in areas where the portion of income spent on food is comparatively low.

\section{Developing countries}

Largely due to the lack of rapid industrialization and resultant cheap labour, renewable resources are generally utilized better and there is little separation of crop and animals and minimal mechanization as cost of labour makes use of tractors and fossil fucl uneconomical. Furthermore, services for such equipment are generally poor with a lack of spare parts when they are necded. In fact many developing countries could avoid the problems stated above in developed countries.

\section{Plant-soil-animal interaction}

The positive effects that herbivores can contribute to soil and plants are well illustrated in work from Sri Lanka (Pathriana et al., 1996). Here, cattle were grazing under coconut trees at a very high stocking density. One group grazed without being given supplementary feeding. Another group had access to rice straw from outside and another group had, in addition, to rice straw a supplement of rice bran. There was an ungrazed control treatment. The main results are given in Table 1. Here it can be seen how plants, animals and soil benefitted both from grazing and supplementation. The grazing itself increased coconut yield by $16 \%$ and the water holding capacity also increased, no doubt as a result of a more rapid turnover of biomass growing under the trees. The cffect of supplements can be seen in terms of the effect on reproduction of the cattle, in milk production by the cattle and the length of the lactation. There was also an increase in $\mathrm{P}$ and $\mathrm{K}$ content of the soil.

TABLE 1

Effect of cattle grazing under coconut trees, on coconut yield, performance of 12 grazing cows and on soil characteristics

\begin{tabular}{lcccccc}
\hline Coconut yield & Copra kg/ \\
nut/palm/year & palm/year & $\begin{array}{c}\text { Calves } \\
\text { no./year } \\
\text { animal }\end{array}$ & $\begin{array}{c}\text { Milk yield } \\
\text { kg/year }\end{array}$ & $\begin{array}{c}\text { Lacta- } \\
\text { tion days }\end{array}$ & $\begin{array}{c}\text { Water-holding } \\
\text { capacity of soil } \\
\text { mm/m }\end{array}$ \\
\hline UG & 41.1 & 11.1 & - & - & - & 16.9 \\
G & 47.9 & 13.3 & 0.3 & 181 & 201 & 18.3 \\
GS & 50.6 & 14.1 & 0.6 & 405 & 264 & 18.9 \\
GSS & 57.4 & 16.7 & 0.9 & 664 & 282 & 17.6 \\
SE & 2.0 & 0.5 & 0.03 & 25 & 4 & - \\
\hline
\end{tabular}

$\mathrm{UG}=$ ungrazed $\mathrm{G}=$ grazed $\mathrm{GS}=$ supplemented with rice straw, GSS = supplemented with rice straw and rice bran 
The supplement from outside the grazing system contained N, P and K and this indirectly provided fertilizer for the soil with resulting effects of a further increase in coconut yield. Thus an important benefit of animal production could easily have been overlooked if the effect on coconut yield had not been recorded. There is relatively little information available on possible effects of animals grazing under trees, again partly due to the separation of agriculture from forestry. Often, animals are thought to have negative effects on the trees and often bringing in food from outside the system is not seen as an indirect source of fertilizer. A similar appreciation of food from outside being recognized as fertilizer is casily seen practised by Kikuyo farmers near to Nairobi in Kenya. Here small dairy farmers with 2 to 4 crossbred cows normally keep 200 to 300 laying or broiler chickens. Here, chicken food is brought in, but the main concentrate for the cattle consists of sun-dried chicken manure and the main roughage is maize straw and cut-and-carry grass from roadsides. Thus the outputs from the farms are milk and poultry products and the input to the farms is fertilizer via poultry food.

\section{Use of excreta for production of biogas}

The usc of animal excreta for production of biogas has long been practiced in countries such as China and India. The differences between them are in the design of biodigesters. In recent years, very cheap biodigesters have been introduced to countries, such as Victnam, to a large extent initiated by Dr T.R. Preston, UTA, Cambodia. There are different methods and here the biogas slurry, still containing most of the N, P and K from the fecd:

a. can be used directly as a fertilizer for crops,

b. can be led into small fishponds and serve as fertilizer for plankton, which in turn is consumed by fish. The pond water can in turn be used as irrigation water for crops,

c. can be used to fertilize water plants in a pond such as Lemna species or duckweed. These plants can in turn be used as high quality animal and/or human food.

\section{Direct use of excreta}

Excreta of course is the major use as fertilizer for crops, a practice used for millinia. However, excreta can also be used directly to fertilize fishponds. Thus in Vietnam, and in other countries as well, animal houses are often situated above fishponds in which the excreta directly fertilizes the fishpond. This is true both for pigs, chicken and duck houses. The fish production forms a substantial part of the income. The pond water needs to be renewed occasionally and the water used for irrigation still containing most of the N, P and $\mathrm{K}$ from the manure. There are so 
many so-called 'developed' countries which can learn from such attention to resource management.

Another system often used in Vietnam is to have a duck/fish combination. Duck food, such as rice bran or brewers grains, is given to the ducks near to the fishpond. The duck then fertilize the fishpond by their excreta. Here, both duck and fish production is generated and, again, the water from the pond and be used for irrigation.

Nutrients from the excreta of monogastric animals can of course be further extracted by ruminants. As mentioned earlier, sun-dried poultry manure is used by Kikuyo farmers as concentrate for cattle. Poultry manure is used in several places as well as solid pig manure. Ruminant manure can then be processed via biogas etc. Unpublished work from Vietnam indicates that biogas slurry formed from a given amount of animal manure is better than fertilizer from the animal manure itself. The fermentation process in digestion removes all pathogenic bacteria that might be there.

\section{Increased nutrient extraction from by-products}

Extraction of biomass not suitable for human food through different systems such as animal feed, excreta, biogas, etc. does not in itself directly increase human food. It obviously utilizes renewable resource far better and with much less input of fossil fuel. It also produces animal products such as draught power for cultivation and meat, milk, and eggs for human consumption.

It is worth considering why a great deal of biomass is not suitable as human food. This is largely due to the cellulosic nature of the largest proportion of biomass. Its partial protection by lignin also means that only a limited amount can be extracted by cellulolytic bacteria in ruminant animals. It is however possible by cellulolytic enzymes to hydrolyse cellulose to glucose. It is also possible to hydrolyse hemicellulose by hemicellulases and use the sugars as a fermentation substrate leading to alcohol or other fermentation products.

It is possible by chemical treatment, e.g. by alkali treatment to increase access to hemicellulose and cellulose by cellulolytic organisms and by oxidation methods, e.g. using $\mathrm{O}_{3}$ or $\mathrm{H}_{2} \mathrm{O}_{2}$, to oxidize some of the lignin. However, this is of advantage only to ruminants, as anaerobic rumen bacteria are needed to ferment cellulosic materials. In recent years there has been some progress in steam trcatment, mainly led by increasing use of baggase from sugar cane. A mild steam treatment will dislodge some of the bond between hemicellulose and lignin and this substantially increases digestibility of straw (Castro et al., 1993). However, a harsh steam treatment can dislodge all of the lignin, which can be removed from the steam-treated biomass by mild alkali. It is possible for instance to separate straw into three major fractions, namely cellulose, hemicellulose and lignin. Cellulose can be used in papermaking but can also be hydrolyzed by cel- 
lulose enzymes to glucose, which in turn can be used for many purposes including human food and as a substrate for fermentation. Hemicellulose can be used as a syrup in animal feeding and also as a substrate for fermentation. Lignin can have many uses, such as biodegradable plastic and paint, and can be used to precipitate proteins and even to protect protein from degradation (Zahidifar et al., 2002). There is thus potentially a vast source of biomass that can be converted to human food and industrial raw materials.

The concept of total resource use, via different routes, also implies that the food given the best fecd conversion for the animal is not necessarily the best in the total system. The value of the manure may be more important for downstream production than is maximal extraction by the animal.

\section{Potential problems with plant-soil-livestock imbalance}

\section{Positive nutrient balance}

In recent years there has been an increase in urban and peri-urban livestock production in many countries with little or no regulations of numbers or potential pollution problems. In many countries the accumulation that occur of $\mathrm{N}, \mathrm{P}$ and $\mathrm{K}$ is often not recognized before it is too late when soil and waterways are polluted. There is a great need to seriously look at nutrient balances in many peri-urban areas. Sometimes large piggeries and poultry units are set up with little attention paid to the pollution problems that they may create. Similarly, large and indeed, smaller dairy units are placed in urban and peri-urban areas with food being transported from rural areas to feed dairy cows in peri-urban arcas. This creates problems as the excreta accumulate and pollute the small areas of land available for the manure. On the other hand, as seen for instance in Ho Chi Minh City, small dairy units are using city by-products, e.g. cassava waste and brewers grains. The manure is being bought by cocoa farmers in the rural areas. Here, the cattle can be seen to some extent as waste processors, i.e. extracting nutrients from city by-products. It is essential here that the excreta are being transported away from the area.

When feeds are brought in from rural areas to feed dairy cattie in peri-urban areas, there are problems looming unless utmost attention is given to disposal of manurc. In any case, it is better for the environment if the feed or roughage is used at or near sites of production as the resulting manure can be used directly. It is cheaper to transport milk from rural areas to the city rather than roughage from rural areas to the peri-urban areas. It is better for rural development and rural poverty alleviation if small farmers, perhaps co-operatives, can deliver milk to cities so that a city demand for milk can be used for rural poverty alleviation rather than to support a few large peri-urban dairy or beef farms. 
Negative nutrient balance

There are also situations in which livestock management is such that a nutrient deficit is the problem. This occurs in more extensive situations in which livestock graze over large areas and are kept in corals at night. The manure excreted at night is seldom brought back to grazing areas, resulting in nutrient deficits, soil deterioration, and reduction in nutrients and soil organic matter. It can also occur in cut-and-carry systems where grass is collected from roadsides and other common land areas where manure is retained near to homesteads and never brought back to fertilize common land areas from which plants are collected to feed animals. Since the land areas arc common, there is little incentive to ensure a nutrient balance. As a result, soil fertility and plant production decrease in such areas and even cause erosion problems in some arid areas due to decrease in soil organic matter content. There is a great need for environmental budgeting both in areas exposed to depletion and areas exposed to excess.

\section{What are the factors which can drive better use of renewable resources?}

There is little doubt that price of alternative resources makes a big difference as does the price of labour. The inefficient use of biomass or crop residues in the so-called developed countries is largely due to low prices of alternative energy source, in this case fossil fuel, and to the high cost of labour. In fact there is generally a negative relationship between resource and labour efficiency as discussed by Von Weizacker (1996). The high cost of labour is in fact fuelled by the fact that both employers and labour have to pay taxes based on labour and income from labour. A change in cost of fuel could alter things drastically. If all or most taxes could be collected by taxing resourees rather than labour, there could be enormous changes resulting in the reduction of greenhouse gas production, increases in plant, soil and animal interactions and a reduction in the separation of crop and animal production. This has not been pursued in many developed countries where cheap fossil fuel and expensive labour costs are the norm. There is beginning of a recognition, however, in some countries that many of the present systems are not sustainable and most countries are united in wishing to reduce greenhouse gasses and maximize the use of renewable resources, including biomass, and the exploitation of sun, wind and waves as sources of encrgy. 


\section{REFERENCES}

Blaxter K.L., 1989. Energy Metabolism in Animals and Man. Cambridge University Press, Cambridge, UK

Castro F.B., Hotten P.M., Orskov E.R., 1993. The potential of dilute-acid hydrolysis as a treatment of improving the nutritional quality of industrial lignocellulosic by-products. Anim. Feed Sci. Tech. 42, 39-53

Curry D., 2002. Farming and Food. A Sustainable Future. Report of Policy Commission on the Future of Farming and Food. United Kingdom, Department of Government and Home Affairs

Ørskov E.R., 1992. Reorientation of livestock research in Poland. J. Anim. Feed Sci. 1, 3-7

Pathirana K.K., Mangalika U.L.P., Liyanage M. De S., Ørskov E.R., 1996. Effect of grazing and supplementation in a coconut plantation on cattle production, coconut yield and soil fertility. Outlook Agr. 25 (3), 187-192

Von Weizacker E.U., 1996. Green is the Colour of Money. Down to Earth. 4 January Issue, pp. 27-32

Zahedifar M., Castro F.B., Ørskov E.R., 2002. Effect of hydrolytic lignin on formation of protein-lignin complexes and protein degradation by rumen microbes. Anim. Feed Sci. Tech. 95, 83-92

\section{STRESZCZENIE}

Rozważania dotyczące zagospodarowania zasobów pasz w różnych ekosystemach i socjo-ekonomicznych warunkach

W artykule przedyskutowano niektóre zagadnienia dotyczące zagospodarowania zasobów pasz. Podkreślono, że działania te zazwyczaj nie są zadowalające w krajach rozwijających się i wynikają z wysokich kosztów pracy oraz niskich kosztów źródeł energii. Podobnie, subsydiowane rolnictwo krajów Unii Europejskiej i innych krajów ma wiele problemów związanych z degradacją środowiska, ponieważ subsydia stanowią część kosztów utrzymania ziemi itp., i stanowią niewielką pozycję w przychodach gospodarstwa. Drastyczne zmiany w Wspólnej Polityce Rolnej (Common Agricultural Policy) są konicczne w najbliższej dekadzie, także z uwagi na poszerzanie się Unii Europejskicj o nowe kraje.

Zagospodarowanic zasobów paszowych praktykowane jest w wielu rozwijających się krajach, w których produkcja zwierzęca i roślinna traktowana jest łącznie, i w których produkty uboczne pochodzące z upraw i odchody zwierzęce są wartościowymi źródłami paszy. Gdy produkcja roślinna i zwicrzęca nie jest traktowana łącznie, $z$ czym mamy do czynienia w t.z.w. krajach rozwiniętych, to uboczne produkty z upraw, jak i odchody zwierzęce traktowane są jako odpady.

Podano przykłady systemów, w których roślina, zwierzę i ziemia są ujmowane holistycznic. Podano także przykłady w jaki sposób można zwiększyć produkcję żywności dla ludzi poprzez odblokowanic wiązań między ligniną, celulozą i hemicelulozą w odpadach roślinnych. 